\title{
Genetic variability and linear relationships between plant architecture and maize grain yield
}

\author{
Alberto Cargnelutti Filho ${ }^{1^{*}}$ Daniela Lixinski Silveira ${ }^{2}$ iD Bruna Mendonça Alves $^{2}$ (D) \\ Fernanda Carini' ${ }^{2}$ Cirineu Tolfo Bandeira² ${ }^{2}$ Rafael Vieira Pezzini² ${ }^{2}$ D
}

${ }^{1}$ Departamento de Fitotecnia, Centro de Ciências Rurais (CCR), Universidade Federal de Santa Maria (UFSM), Santa Maria, RS, Brasil.
E-mail: alberto.cargnelutti.filho@gmail.com. *Corresponding author.
${ }^{2}$ Programa de Pós-graduação em Agronomia, Centro de Ciências Rurais (CCR), Universidade Federal de Santa Maria (UFSM), Santa Maria, RS, Brasil.

ABSTRACT: The objectives of this study were to analyze whether there is genetic variability and assess the linear relationships between plant architecture and maize grain yield. Three experiments were carried out in a complete randomized block design. A group of 51 cultivars was assessed in relation to 22 traits: number of leaves, plant height, ear height, leaf angle, leaf length, leaf width, leaf area, and grain yield. Individual analyses of variance were performed, the assumptions of normality of errors and homogeneity of residual variances were tested, and means were grouped by the Scott-Knott test. The phenotypic correlation matrix was constructed using the 22 traits of the 51 cultivars. Results showed that there is genetic variability among cultivars for number of leaves, plant height, ear height, leaf angle, leaf length, leaf width, leaf area, and grain yield. Leaves close to the ear have smaller leaf angle and larger length, width, and area of the leaves. Leaf angle gradually increases towards the lower and upper ends of the plant. Length, width, and area gradually decreases in leaves towards the lower and upper ends of the plant. Cultivars with higher number of leaves and larger leaf area are associated with higher grain yield.

Key words: Zea mays L., number of leaves, leaf angle, leaf area.

Variabilidade genética e relações lineares entre a arquitetura de planta e a produtividade de grãos de milho

RESUMO: Os objetivos deste trabalho foram verificar se há variabilidade genética e avaliar as relações lineares entre a arquitetura de planta e a produtividade de grãos de milho. Foram conduzidos três experimentos no delineamento blocos completos ao acaso. Em 51 cultivares, foram avaliados caracteres relacionados ao número de folhas, às alturas de planta e de espiga, ao ângulo foliar, ao comprimento da folha, a largura da folha, a área foliar e a produtividade de grãos, totalizando 22 caracteres. Foram realizadas análises de variância individuais, verificados os pressupostos de normalidade dos erros e homogeneidade de variâncias residuais e agrupadas as médias de cultivares pelo teste de Scott-Knott. Foi determinada a matriz de correlação fenotípica entre os 22 caracteres das 51 cultivares. Há variabilidade genética entre as cultivares em relação ao número de folhas, alturas de planta e de espiga, ângulo foliar, comprimento da folha, largura da folha, área foliar e produtividade de grãos. Folhas localizadas próximas a espiga apresentam menor ângulo foliar e maiores comprimento da folha, largura da folha e área foliar. $O$ ângulo foliar aumenta gradativamente em direção as folhas da extremidade inferior e superior da planta. O comprimento da folha, a largura da folha e a área foliar diminuem gradativamente em direção as folhas da extremidade inferior e superior da planta. Cultivares com maior número de folhas e maior área foliar estão associadas a plantas com maior produtividade de grãos.

Palavras-chave: Zea mays L., número de folhas, ângulo foliar, área foliar.

\section{INTRODUCTION}

Because of the great importance of maize (Zea mays L.), plant breeding programs have developed new genotypes seeking to improve plant architecture and enhance grain yield. Therefore, it is necessary to evaluate the genotypes regarding plant architecture traits such as leaf number, plant height, ear height, leaf angle, leaf length, leaf width, leaf area, and grain yield to distinguish the genotypes in the crop environment.

Traits related to plant architecture in maize are important to define population and spatial distribution of plants in the area. Adequate spatial distribution and population can increase the interception of solar radiation and its use efficiency, as well as increase grain yield due to the influence on leaf area index, leaf angle, and leaf distribution in the canopy (ARGENTA et al., 2001). To achieve high grain yields, it is important to understand the morphological, physiological, phenological, and allometric characteristics that contribute to better adaptation of maize to high plant densities (SANGOI et al., 2002).

One of the objectives of maize breeding programs is to select plants with high grain yield. For 
a direct selection of plants with higher grain yield, it is necessary to harvest the ears to obtain grain weight, destroying the plant. Plant architecture traits, such as leaf number, plant height, ear height, leaf angle, leaf length, leaf width, and leaf area can be measured in a non-destructive way. An indirect selection, without destroying the plant, is possible when there are linear relationships between the mentioned traits and grain yield. The Pearson linear correlation coefficient (r), which varies between -1 (perfect negative linear relationship) and 1 (perfect positive linear relationship), is able to measure the strength of association between two variables and can be used to indicate the traits for indirect plant selection.

Studies have been carried out to characterize maize genotypes regarding plant architecture and grain yield (VIEIRA JUNIOR et al., 2005; VIEIRA JUNIOR et al., 2006; BELLO et al., 2010; KU et al., 2010; TIAN et al., 2011; HANASHIRO et al., 2013; WASSOM, 2013; BEKELE \& RAO, 2014; ZHANG et al., 2014; NARDINO et al., 2016; HUANG et al., 2017; BORELLA et al., 2019) and the linear relationships between those traits (BELLO et al., 2010; KU et al., 2010; TIAN et al., 2011; BEKELE \& RAO, 2014; OGUNNIYAN \& OLAKOJO, 2014; NARDINO et al., 2016). In general, these studies have shown a wide genetic variability and the possibility of using plant architecture traits for indirect selection considering grain yield. Plant architecture traits, grain yield, and the relationship between them, should; therefore, be constantly assessed in the new genotypes developed in plant breeding programs.

It is believed that maize cultivars have varied plant architecture and grain yield, and that it is possible to find linear relationships between these traits. Thus, the objective of this research was to verify the existence of genetic variability and to evaluate the linear relationships between plant architecture and maize grain yield.

\section{MATERIALS AND METHODS}

Three experiments with maize (Zea mays L.) were carried out in the experimental area of the Department of Agricultural Sciences at the Federal University of Santa Maria, Santa Maria, state of Rio Grande do Sul (2942'S; 53⒋'W; 95 m above sea level). According to the Köppen classification, the climate is humid subtropical (Cfa), with hot summers and no dry season (ALVARES et al., 2013). The soil is classified as dystrophic Red Argisol (SANTOS et al., 2018) with the following physical and chemical (0 - $20 \mathrm{~cm}$ depth) characteristics: $\mathrm{pH}_{\mathrm{H} 2 \mathrm{O}}$ 1:1: 5.8; Ca:
$5.7 \mathrm{cmol}_{\mathrm{c}} \mathrm{dm}^{-3} ; \mathrm{Mg}: 2.4 \mathrm{cmol}_{\mathrm{c}} \mathrm{dm}^{-3} ; \mathrm{Al}: 0.0 \mathrm{cmol}_{\mathrm{c}}$ $\mathrm{dm}^{-3}$; H+Al: $3.5 \mathrm{cmol}_{\mathrm{c}} \mathrm{dm}^{-3}$; SMP index: 6.2; organic matter: $2.4 \%$; clay content: $29.0 \%$; S: $13.3 \mathrm{mg} \mathrm{dm}^{-}$ 3; P (Mehlich): $25.7 \mathrm{mg} \mathrm{dm}^{-3}$; K: $0.696 \mathrm{cmol}_{\mathrm{c}} \mathrm{dm}^{-3}$; $\mathrm{CTC}_{\mathrm{pH} 7}: 12.4 \mathrm{cmol}_{\mathrm{c}} \mathrm{dm}^{-3} ; \mathrm{Cu}: 1.28 \mathrm{mg} \mathrm{dm}^{-3} ; \mathrm{Zn}: 0.753$ $\mathrm{mg} \mathrm{dm}$; and B: $0.1 \mathrm{mg} \mathrm{dm}^{-3}$.

Experiment 1 consisted of 26 maize cultivars from the maize cultivar trial network of Rio Grande do Sul, which is coordinated by the State Agricultural Research Foundation (FEPAGRO). Experiments 2 and 3 refer to the national maize cultivar trial network coordinated by the Brazilian Agricultural Research Corporation (EMBRAPA). Experiment 2 included 13 cultivars of early cycle maize from the national trial in the south and experiment 3 included 12 super-early maize cultivars from the national trial (Table 1).

The experiments were carried out in a complete randomized block design, with three replicates in experiment 1 and two replicates in experiments 2 and 3. Plots in all three experiments consisted of two 5-m-rows, $0.80 \mathrm{~m}$ apart, and plants in a $0.20 \mathrm{~m}$ in-row spacing. Cultivars were sowed by hand on November 19, 2016, using basal fertilization $\left(20 \mathrm{~kg} \mathrm{ha}^{-1}\right.$ of $\mathrm{N}, 80 \mathrm{~kg} \mathrm{ha}^{-1}$ of $\mathrm{P}_{2} \mathrm{O}_{5}$, and $80 \mathrm{~kg} \mathrm{ha}^{-1}$ of $\mathrm{K}_{2} \mathrm{O}$ ).

After crop emergence and establishment, plant thinning was carried out by hand, and plant density was adjusted to 62,500 plants per hectare. Topdressing fertilization was divided into two applications: on the $4^{\text {th }}$ and $19^{\text {th }}$ of December 2016, when the plants had four and eight expanded leaves, respectively. Each application consisted of $90 \mathrm{~kg} \mathrm{ha}^{-1}$ of $\mathrm{N}$, totalizing $180 \mathrm{~kg} \mathrm{ha}^{-1}$ of $\mathrm{N}$ topdressed.

At flowering $(50 \%$ stamens with pollenreleasing anthers), one plant in each plot was labeled, and the leaves were numbered in ascending order from the plant base (the leaf closest to the soil was numbered as 1). In each plant, the number of leaves (NL), the number of leaves below the ear (NLBE) and the number of leaves above the ear (NLAE) were counted. Plant height $(\mathrm{PH}$, in $\mathrm{cm})$ and ear insertion height $(\mathrm{EIH}$, in $\mathrm{cm})$ were measured. Leaf angle $(\mathrm{AG}$, in degrees) was measured on each leaf of each plant. The leaf insertion angle represents the inclination between the central rib of the leaf blade and the stem and was measured using a "Clinometer ${ }^{\circledR}$ "+ bubble level $\left.{ }^{\circledR "}\right)$. Leaf length (LL, in $\mathrm{cm}$ ) and maximum leaf width (LW, in $\mathrm{cm}$ ) were measured. The leaf area (LA, in $\mathrm{cm}^{2}$ ) was estimated for each leaf using the equation: $\mathrm{LA}=\mathrm{LL} \times \mathrm{LW} \times 0.75$ (ELINGS, 2000).

Following, each plant was divided into portions (lower, middle and upper), according to the 
Table 1 - Cultivar, company, genetic basis, cycle, and grain texture of the maize cultivars assessed in the three experiments.

\begin{tabular}{|c|c|c|c|c|}
\hline Cultivar & Company & Genetic basis & Cycle & Grain texture \\
\hline $20 \mathrm{~A} 55$ & Morgan Seeds & Triple hybrid & Early & Semi-hard \\
\hline $30 \mathrm{~A} 68$ & Morgan Seeds & Simple hybrid & Super-early & Semi-hard \\
\hline $30 \mathrm{~F} 53$ & Pioneer & Simple hybrid & Early & Semi dentade \\
\hline AG8780 & Agroceres Seeds & Simple hybrid & Early & Semi dentade \\
\hline AG9025 & Agroceres Seeds & Simple hybrid & Super-early & Semi dentade \\
\hline AM9724 & Melhoramento Agropastoril & Simple hybrid & Super-early & Dentade \\
\hline AS1666 & Agroeste & Simple hybrid & Super-early & Semi dentade \\
\hline AS1677 & Agroeste & Simple hybrid & Super-early & Semi dentade \\
\hline BM3066 & Biomatrix & Simple hybrid & Early & Semi dentade \\
\hline CD324 & Coodetec & Simple hybrid & Early & Semi-hard \\
\hline CD384 & Coodetec & Triple hybrid & Early & Semi-hard \\
\hline CD393 & Coodetec & Simple hybrid & Early & Hard \\
\hline CD397 & Coodetec & Triple hybrid & Early & Semi dentade \\
\hline Celeron & Syngenta Seeds & Simple hybrid & Super-early & Hard \\
\hline DKB230 & Dekalb & Simple hybrid & Super-early & Semi dentade \\
\hline DKB290 & Dekalb & Simple hybrid & Early & Semi dentade \\
\hline MS2010 & Melhoramento Agropastoril & Simple hybrid & Early & Semi dentade \\
\hline MS2013 & Melhoramento Agropastoril & Simple hybrid & Early & Semi-hard \\
\hline MS3022 & Melhoramento Agropastoril & Triple hybrid & Early & Hard \\
\hline P1630 & Pioneer & Simple hybrid & Super-early & Semi dentade \\
\hline P2530 & Pioneer & Simple hybrid & Super-early & Semi-hard \\
\hline SHS7915 & Santa Helena Seeds & Simple hybrid & Super-early & Semi dentade \\
\hline StatusVIP3 & Syngenta Seeds & Simple hybrid & Early & Hard \\
\hline StatusVIP & Syngenta Seeds & Simple hybrid & Early & Hard \\
\hline SX7331 & Syngenta Seeds & Simple hybrid & Early & Hard \\
\hline XB6012 & Semeali & Simple hybrid & Early & Semi-hard \\
\hline \multicolumn{5}{|c|}{ - } \\
\hline ALPiratininga & $\mathrm{DSMM} / \mathrm{CATI}$ & Variety & Early & Dentade/Soft \\
\hline Embrapa1M1642 & Embrapa & Simple hybrid & Early & Semi-hard \\
\hline XB61493 & Semeali & Simple hybrid & Early & Semi-hard \\
\hline 70XB01 & Semeali & Simple hybrid & Early & Semi-hard \\
\hline Balu383VIP3 & Balu Seeds & Simple hybrid & Early & - \\
\hline Balu388VIP3 & Balu Seeds & Simple hybrid & Early & - \\
\hline Exp929791 & Balu Seeds & Simple hybrid & Early & - \\
\hline EXP937891 & Balu Seeds & Simple hybrid & Early & - \\
\hline Exp918391 & Balu Seeds & Simple hybrid & Early & - \\
\hline Balu280PRO & Balu Seeds & Simple hybrid & Early & - \\
\hline Balu188 & Balu Seeds & Triple hybrid & Early & - \\
\hline Balu761 & Balu Seeds & Double hybrid & Early & - \\
\hline \multicolumn{5}{|c|}{ } \\
\hline $98 \mathrm{CV} 02$ & DSMM/CATI & Variety & Super-early & Semi-hard \\
\hline 70XB03 & Semeali & Simple hybrid modified & Super-early & - \\
\hline Exp917694 & Balu Seeds & Simple hybrid & Super-early & - \\
\hline Exp93294 & Balu Seeds & Simple hybrid & Super-early & - \\
\hline EXP942491 & Balu Seeds & Simple hybrid & Super-early & - \\
\hline EXP942494 & Balu Seeds & Simple hybrid & Super-early & - \\
\hline EXP978791 & Balu Seeds & Simple hybrid & Super-early & - \\
\hline EXP978894 & Balu Seeds & Simple hybrid & Super-early & - \\
\hline Balu280PRO & Balu Seeds & Simple hybrid & Super-early & - \\
\hline Balu188 & Balu Seeds & Triple hybrid & Super-early & - \\
\hline Balu761 & Balu Seeds & Double hybrid & Super-early & - \\
\hline
\end{tabular}

Source: The information about the cultivars in Experiment 1 was provided by the maize cultivar experiment network in Rio Grande do Sul coordinated by the State Agricultural Research Foundation (FEPAGRO). The cultivars in Experiments 2 and 3 were provided by the national maize cultivar experiment network coordinated by the Brazilian Agricultural Research Corporation (Embrapa), at $<$ https://www.embrapa.br/milho-e-sorgo/solucoes-tecnologicas/ensaionacional $>$.

Ciência Rural, v.50, n.10, 2020. 
number of leaves. Plants with 12, 15 and 18 leaves were divided into portions with 4, 5 and 6 leaves each, respectively. The plants with number of leaves not multiple of three had the canopy divided as follows: plants with 13 leaves ( 5 leaves in the lower portion, 4 leaves in the middle portion, and 4 leaves in the upper portion); plants with 14 leaves (5 leaves in the lower portion, 5 leaves in the middle portion, and 4 leaves in the upper portion); plants with 16 leaves (6 leaves in the lower portion, 5 leaves in the middle portion,and 5 leaves in the upper portion); and plants with 17 leaves (6 leaves in the lower portion, 6 leaves in the middle portion, and 5 leaves in the upper portion).

Measurements AG, LL, LW, and LA of each leaf were used to calculate the following traits: plant leaf angle (AGP, in degrees; average AG of plant leaves); leaf angle of the lower portion (AGL, in degrees; average AG of the lower portion leaves); leaf angle of the middle portion (AGM, in degrees; average $\mathrm{AG}$ of the middle portion leaves); leaf angle of the upper portion (AGU, in degrees; average AG of the upper portion leaves); plant leaf length (LLP, in $\mathrm{cm}$; average LL of plant leaves); leaf length of the lower portion (LLL, in $\mathrm{cm}$; average LL of the lower portion leaves); leaf length of the middle portion (LLM, in cm; average LL of middle portion leaves); leaf length of the upper portion (LLU, in $\mathrm{cm}$; average LL of the upper portion leaves); plant leaf width (LWP, in cm; average LW of plant leaves); leaf width of the lower portion (LWL, in $\mathrm{cm}$; average LW of the lower portion leaves); leaf width of the middle portion (LWM, in $\mathrm{cm}$; average LW of the middle portion leaves); leaf width of the upper portion (LWU, in $\mathrm{cm}$, average LW of the upper portion leaves); plant leaf area (LAP, in $\mathrm{cm}^{2}$; LA of the plant leaves); leaf area of the lower portion (LAL, in $\mathrm{cm}^{2}$; LA of the lower portion leaves); leaf area of the middle portion (LAM, in $\mathrm{cm}^{2}$; LA of the middle portion leaves); and leaf area of the upper portion (LAU, in $\mathrm{cm}^{2}$; LA of upper portion leaves).

At physiological maturity, when $50 \%$ of the kernels have formed black layers at the point of attachment of the kernel to the cob, the corn ears were harvested and threshed. The grain was weighed using a digital scale and the moisture content was determined using an electronic moisture meter. Grain mass was corrected to $13 \%$ moisture and grain yield was calculated (GY, in g plant $^{-1}$ ).

In all three experiments, analysis of variance was carried out for each of the 22 traits (NL, NLBE, NLAE, PH, EIH, AGP, AGL, AGM, AGU, LLP, LLL, LLM, LLU, LWP, LWL, LWM, LWU, LAP, LAL, LAM, LAU, and GY), using the following mathematical model: $Y_{i j}=\mu+C_{i}+B_{j}+\varepsilon_{i j}$, where $\mathrm{Y}_{\mathrm{ij}}$ represents the value of the variable $Y$ of the $i^{\text {th }}$ cultivar $(i=1,2, \ldots, n)$ in the $j^{\text {th }}$ repetition (block) $(j=1,2, \ldots, r)$; $\mu$ is the overall mean; $C_{i}$ is the effect of the $i^{\text {th }}$ cultivar $(\mathrm{i}=1,2, \ldots, \mathrm{n})$ (fixed effect); $B_{j}$ is the effect of the $\mathrm{j}^{\text {th }}$ repetition (block) $(\mathrm{j}=1,2, \ldots, \mathrm{r})$; and $\varepsilon_{i j}$ is the effect of the experimental error referring to the observation $Y_{i j}$, supposedly normal, independent and distributed with zero mean and common variance $\sigma^{2}$ (STORCK et al., 2016). The following statistics were recorded: $F$ test for cultivar $(\mathrm{F})$, mean, and coefficient of variation (CV). The p-value of the Kolmogorov-Smirnov test was determined for error normality and the p-value of the Bartlett test was determined for residual variance homogeneity. The selective accuracy was estimated using the equation $\mathrm{SA}=(1-1 / \mathrm{F})^{0,5}$ (RESENDE \& DUARTE, 2007). The cultivar means were grouped using the Scott-Knott test, at 5\% significance.

The Pearson correlation coefficient matrix (r, phenotypic correlation) between the 22 traits was constructed using the means of the repetitions. The Student $t$ test at $5 \%$ significance was used to verify the coefficient significance, with $n-2=49$ degrees of freedom, where $n=51$ maize cultivars. Statistical analyzes were performed using Microsoft Office Excel application and the Genes program (CRUZ, 2016).

\section{RESULTS AND DISCUSSION}

In the 66 experimental cases $(22$ traits $\times$ three experiments), the p-value of the KolmogorovSmirnov tests ranged between 0.106 and 0.999 and the Bartlett test between 0.020 and 0.999 (Table 2). For both tests, the greater the p-value the greater the evidence of error normality and residual variance homogeneity. Therefore, at a $2 \%$ significance level, it can be affirmed that the assumptions were met in $100 \%$ of the cases and the results of the analysis of variance and Scott-Knott test were statistically valid (STORCK et al., 2016).

The $\mathrm{F}$ test of the analysis of variance showed significant effect $(\mathrm{p} \leq 0.05)$ of cultivars in 22 traits $(100 \%)$ in experiment 1 (maize cultivars from Rio Grande do Sul); 4 traits (18.2\%) in experiment 2 (early cycle south maize cultivars from the national experiment); and 5 traits $(22.7 \%)$ in experiment 3 (super-early maize cultivar from the national trial in the Southern Region) (Table 2). Results indicated that it is possible to select superior genotypes from the genetic variability existing in the germplasm, especially among the 26 cultivars in experiment 1. The experiments 2 and 3 had a lower number of replications and cultivars than experiment 1 . This 
Table 2 - Values of the F test for: cultivar (F), mean, coefficient of variation (CV), selective accuracy (SA), p-value of the Kolmogorov-Smirnov test (KS) for error normality and p-value of the Bartlett test for homogeneity of residual variances for 22 maize traits assessed in three experiments.

\begin{tabular}{|c|c|c|c|c|c|c|c|c|c|c|c|}
\hline Statistics & NL & NLBE & NLAE & $\mathrm{PH}$ & $\mathrm{EIH}$ & AGP & AGL & AGM & AGU & LLP & LLL \\
\hline \multicolumn{12}{|c|}{ 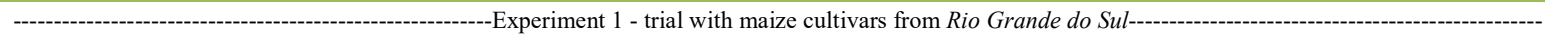 } \\
\hline F & $7.02^{*}$ & $4.51^{*}$ & $2.51^{*}$ & $3.38^{*}$ & $4.53^{*}$ & $5.85^{*}$ & $5.31^{*}$ & $6.00^{*}$ & $5.54^{*}$ & $8.32^{*}$ & $4.65^{*}$ \\
\hline Mean & 14.87 & 7.95 & 6.92 & 231.23 & 120.14 & 23.97 & 27.75 & 22.15 & 21.55 & 80.39 & 77.13 \\
\hline CV(\%) & 5.32 & 9.56 & 11.65 & 4.91 & 7.83 & 10.13 & 10.70 & 12.76 & 15.54 & 4.33 & 7.67 \\
\hline SA & 0.93 & 0.88 & 0.78 & 0.84 & 0.88 & 0.91 & 0.90 & 0.91 & 0.91 & 0.94 & 0.89 \\
\hline KS & 0.624 & 0.501 & 0.106 & 0.988 & 0.485 & 0.738 & 0.768 & 0.996 & 0.939 & 0.988 & 0.999 \\
\hline Bartlett & 0.642 & 0.407 & 0.063 & 0.468 & 0.020 & 0.071 & 0.576 & 0.585 & 0.407 & 0.856 & 0.322 \\
\hline \multicolumn{12}{|c|}{ - } \\
\hline F & $0.77 \mathrm{~ns}$ & $0.38 \mathrm{~ns}$ & $1.22 \mathrm{~ns}$ & $2.87^{*}$ & $1.03 \mathrm{~ns}$ & $4.21^{*}$ & $1.62 \mathrm{~ns}$ & $2.53 \mathrm{~ns}$ & $2.57 \mathrm{~ns}$ & $3.30^{*}$ & $2.12 \mathrm{~ns}$ \\
\hline Mean & 15.19 & 8.50 & 6.69 & 242.78 & 129.34 & 23.36 & 27.07 & 20.68 & 22.12 & 84.46 & 79.74 \\
\hline $\mathrm{CV}(\%)$ & 6.71 & 10.98 & 12.08 & 4.98 & 8.79 & 9.52 & 15.63 & 11.58 & 17.37 & 5.61 & 9.86 \\
\hline SA & - & - & 0.42 & 0.81 & 0.16 & 0.87 & 0.62 & 0.78 & 0.78 & 0.83 & 0.73 \\
\hline $\mathrm{KS}$ & 0.436 & 0.771 & 0.522 & 0.967 & 0.844 & 0.995 & 0.623 & 0.951 & 0.999 & 0.984 & 0.996 \\
\hline Bartlett & 0.060 & 0.205 & 0.734 & 0.522 & 0.857 & 0.834 & 0.993 & 0.434 & 0.664 & 0.389 & 0.194 \\
\hline \multicolumn{12}{|c|}{--1 } \\
\hline F & $0.98 \mathrm{~ns}$ & $0.41 \mathrm{~ns}$ & $1.55 \mathrm{~ns}$ & $4.27^{*}$ & $1.63 \mathrm{~ns}$ & $7.11^{*}$ & $2.76 \mathrm{~ns}$ & $3.90^{*}$ & $4.33^{*}$ & $2.73 \mathrm{~ns}$ & $4.87^{*}$ \\
\hline Mean & 14.92 & 8.21 & 6.71 & 234.36 & 123.69 & 23.59 & 28.46 & 20.50 & 21.39 & 81.66 & 75.13 \\
\hline $\mathrm{CV}(\%)$ & 6.70 & 13.48 & 10.50 & 4.72 & 7.79 & 10.27 & 12.72 & 15.52 & 21.11 & 5.15 & 7.30 \\
\hline SA & - & - & 0.60 & 0.88 & 0.62 & 0.93 & 0.80 & 0.86 & 0.88 & 0.80 & 0.89 \\
\hline KS & 0.518 & 0.709 & 0.526 & 0.965 & 0.999 & 0.999 & 0.974 & 0.985 & 0.978 & 0.994 & 0.977 \\
\hline \multirow[t]{2}{*}{ Bartlett } & 0.943 & 0.524 & 0.899 & 0.220 & 0.278 & 0.469 & 0.220 & 0.603 & 0.640 & 0.754 & 0.091 \\
\hline & LLM & LLU & LWP & LWL & LWM & LWU & LAP & $\mathrm{LAL}$ & LAM & LAU & GY \\
\hline \multicolumn{12}{|c|}{ 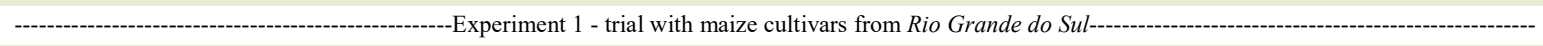 } \\
\hline F & $8.33^{*}$ & $5.01^{*}$ & $3.19^{*}$ & $3.05^{*}$ & $3.70^{*}$ & $2.58^{*}$ & $5.96^{*}$ & $3.46^{*}$ & $5.30^{*}$ & $2.90^{*}$ & $2.35^{*}$ \\
\hline Mean & 96.46 & 67.14 & 8.96 & 8.00 & 10.39 & 8.55 & 8301.07 & 2518.03 & 3684.36 & 2098.67 & 182.07 \\
\hline $\mathrm{CV}(\%)$ & 3.71 & 6.86 & 6.62 & 8.41 & 6.22 & 9.19 & 9.58 & 14.63 & 9.86 & 16.09 & 16.94 \\
\hline SA & 0.94 & 0.89 & 0.83 & 0.82 & 0.85 & 0.78 & 0.91 & 0.84 & 0.90 & 0.81 & 0.76 \\
\hline $\mathrm{KS}$ & 0.985 & 0.896 & 0.999 & 0.639 & 0.999 & 0.944 & 0.543 & 0.754 & 0.864 & 0.993 & 0.704 \\
\hline Bartlett & 0.501 & 0.197 & 0.609 & 0.517 & 0.375 & 0.733 & 0.994 & 0.618 & 0.252 & 0.796 & 0.691 \\
\hline \multicolumn{12}{|c|}{ 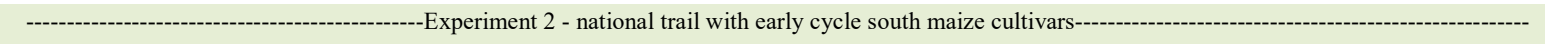 } \\
\hline F & $4.10^{*}$ & $2.13 \mathrm{~ns}$ & $1.55 \mathrm{~ns}$ & $1.88 \mathrm{~ns}$ & $2.42 \mathrm{~ns}$ & $0.95 \mathrm{~ns}$ & $1.06 \mathrm{~ns}$ & $1.87 \mathrm{~ns}$ & $1.02 \mathrm{~ns}$ & $0.82 \mathrm{~ns}$ & $0.74 \mathrm{~ns}$ \\
\hline Mean & 101.44 & 71.66 & 9.05 & 8.07 & 10.43 & 8.68 & 9008.41 & 2663.00 & 4002.95 & 2342.46 & 171.76 \\
\hline $\mathrm{CV}(\%)$ & 4.84 & 8.17 & 6.78 & 7.58 & 5.62 & 11.57 & 14.87 & 19.63 & 13.02 & 22.44 & 19.76 \\
\hline SA & 0.87 & 0.73 & 0.59 & 0.68 & 0.77 & - & 0.25 & 0.68 & 0.13 & - & - \\
\hline KS & 0.986 & 0.999 & 0.988 & 0.375 & 0.981 & 0.971 & 0.944 & 0.757 & 0.739 & 0.901 & 0.888 \\
\hline Bartlett & 0.792 & 0.248 & 0.272 & 0.998 & 0.358 & 0.478 & 0.259 & 0.823 & 0.115 & 0.038 & 0.906 \\
\hline \multicolumn{12}{|c|}{--1-- } \\
\hline $\mathrm{F}$ & $1.78 \mathrm{~ns}$ & $0.69 \mathrm{~ns}$ & $1.06 \mathrm{~ns}$ & $0.97 \mathrm{~ns}$ & $1.22 \mathrm{~ns}$ & $1.05 \mathrm{~ns}$ & $1.42 \mathrm{~ns}$ & $1.87 \mathrm{~ns}$ & $2.20 \mathrm{~ns}$ & $0.74 \mathrm{~ns}$ & $0.78 \mathrm{~ns}$ \\
\hline Mean & 98.90 & 70.69 & 8.81 & 7.86 & 10.29 & 8.30 & 8345.78 & 2429.15 & 3748.13 & 2168.50 & 178.98 \\
\hline $\mathrm{CV}(\%)$ & 4.40 & 13.38 & 6.05 & 8.40 & 5.67 & 10.44 & 9.56 & 15.68 & 7.02 & 24.72 & 17.85 \\
\hline SA & 0.66 & - & 0.24 & - & 0.43 & 0.21 & 0.54 & 0.68 & 0.74 & - & - \\
\hline KS & 0.969 & 0.999 & 0.996 & 0.999 & 0.997 & 0.912 & 0.800 & 0.989 & 0.999 & 0.983 & 0.940 \\
\hline Bartlett & 0.805 & 0.311 & 0.133 & 0.549 & 0.553 & 0.934 & 0.175 & 0.770 & 0.311 & 0.139 & 0.846 \\
\hline
\end{tabular}

Traits: NL: number of leaves; NLBE: number of leaves below the ear; NLAE: number of leaves above the ear; PH: plant height, in cm; EIH: ear insertion height, in cm; AGP: leaf angle of the plant, in degrees; AGL: leaf angle of the lower portion, in degrees; AGM: leaf angle of the middle portion, in degrees; AGU: leaf angle of the upper portion, in degrees; LLP: leaf length of the plant, in cm; LLL: leaf length of the lower portion, in cm; LLM: leaf length of the middle portion, in cm; LLU: leaf length of the upper portion, in cm; LWP: leaf width of the plant, in cm; LWL: leaf width of the lower portion, in cm; LWM: leaf width of the middle portion, in $\mathrm{cm}$; LWU: leaf width of the upper portion, in $\mathrm{cm}$; LAP: leaf area of the plant, in $\mathrm{cm}^{2}$; LAL: leaf area of the lower portion, in $\mathrm{cm}^{2}$; LAM: leaf area of the middle portion, in $\mathrm{cm}^{2}$; LAU: leaf area of the upper portion, in $\mathrm{cm}^{2}$; and GY: grain yield, in $\mathrm{g}$ plant ${ }^{-1} \cdot{ }^{*}$ Significant effect by the $F$ test at $5 \%$ significance; ns non-significant. 
may have contributed to the lack of differences among cultivars in 18 traits in experiment 2 and in 17 traits in experiment 3. A higher number of replications is important to increase cultivar discrimination, and six replications is recommended for experiments with maize cultivars (CARGNELUTTI FILHO et al., 2018). Coefficient of variation (CV) for the 22 traits ranged between $3.71 \%$ and $16.94 \%$ in experiment $1 ; 4.84 \%$ and $22.44 \%$ in experiment 2; and $4.40 \%$ and $24.72 \%$ in experiment 3 (Table 2). CV is a statistical tool widely used to measure the experimental precision. PIMENTEL-GOMES (2009) ranked the CVs in agricultural experiments as follows: low (below 10\%); medium (between 10 and 20\%); high (between 20 and 30\%); and very high (above 30\%). Thus, it can be inferred that for 14, 11, and 11 traits in experiments 1, 2, and 3, respectively, the experimental precision was high (CV under $10 \%$ ); for 8,10 , and 9 traits in experiments 1,2 and 3 , respectively, the experimental precision was medium (CV between 10 and 20\%); and for 1 and 2 traits, in experiments 2 and 3 , respectively, the experimental precision was low (CV between 20 and 30\%).

Selective accuracy (SA), a statistics of experimental precision proposed by RESENDE \& DUARTE (2007), varied between 0.76 and 0.94 , in experiment 1 , between 0.13 and 0.87 , in experiment 2 , and between 0.21 and 0.93 , in experiment 3 . Experiments 2 and 3 reached the lowest SA and, because $F$ was below 1, it was not possible to calculate SA for 5 and 6 traits, respectively (Table 2). Experiment 1 had the highest experimental accuracy compared with experiments 2 and 3, which is in agreement with the findings of CARGNELUTTI FILHO et al. (2018) regarding the need of a higher number of repetitions. Thus, the cases with no significant differences among cultivars identified by the $\mathrm{F}$ test are related to lower experimental precision.

For the 22 traits, using the Scott-Knott test, at $5 \%$ significance, the groups of cultivars varied between 1 and 4, in experiment 1 and between 1 and 2 , in experiments 2 and 3 (Tables 3 and 4). Therefore, the highest number of groups confirmed the greatest variability among cultivars in experiment 1 . This can be explained by the highest experimental precision (lower values of $\mathrm{CV}$ and higher values of AS), highest number of repetitions, and highest number of cultivars. For all three experiments, genetic variability was reported among cultivars for number of leaves, plant height, ear height, leaf angle, leaf length, leaf width, leaf area, and grain yield. Variability of traits in maize genotypes was also observed by VIEIRA JUNIOR et al. (2005), VIEIRA JUNIOR et al. (2006),
HANASHIRO et al. (2013), WASSOM (2013), and BORELLA et al. (2019).

Considering the 51 cultivars $(26,13$ and 12 cultivars in experiments 1,2 and 3, respectively), the number of leaves varied between 12.7 and 17.3, with an average of 15.0 leaves. Similar variations were reported in other studies, between 12 and 16 leaves per plant in 20 maize genotypes (VIEIRA JUNIOR et al., 2005) and between 9 and 14 leaves per plant in 44 maize genotypes (VIEIRA JUNIOR et al., 2006). SANGOI et al. (2002) assessed three genotypes and reported a variation in the average number of leaves between 18.4 and 23.2 leaves. The average number of leaves below the ear (8.2 leaves) was higher in relation to the number of leaves above the ear (6.8 leaves) (Table 3). HANASHIRO et al. (2013) also obtained variation between 6 and 7 leaves above the ear.

Among the 51 cultivars, EIH varied between 103.8 and $150.4 \mathrm{~cm}$ and $\mathrm{PH}$ between 204.4 and $261.0 \mathrm{~cm}$. The average of the 51 cultivars for the relative position of the ears, as calculated by the ratio between $\mathrm{EIH}(123.3 \mathrm{~cm})$ and $\mathrm{PH}(234.9 \mathrm{~cm})$, was $0.52 \mathrm{~cm}$. This may explain the higher number of leaves below the ear (Table 3). HANASHIRO et al. (2013) described similar results for 45 maize genotypes, with EIH varying between 109 and 155 $\mathrm{cm}$, and average of $133 \mathrm{~cm}$. Lower averages for $\mathrm{EIH}$, between 69.12 and $86.19 \mathrm{~cm}$ were reported by KU et al. (2010) and BEKELE \& RAO (2014), respectively. HANASHIRO et al. (2013) reported values between 190 and 257 for $\mathrm{PH}$, with an average of $233 \mathrm{~cm}$. KU et al. (2010) and BEKELE \& RAO (2014) found lower averages for this trait, 201.04 and $188.99 \mathrm{~cm}$, respectively. WASSOM (2013) found a close value for $\mathrm{PH}, 223.13 \mathrm{~cm}$. Higher averages for plant height (between 251 and $302 \mathrm{~cm}$ ) were recorded by SANGOI et al. (2002). Therefore, there is a wide genetic variability of $\mathrm{EIH}$ and $\mathrm{PH}$ in maize. The development of less tall hybrids and ears closer to the ground reduced the number of lodged and broken plants (SANGOI et al., 2002).

Plant leaf angle (AGP) among the 51 cultivars ranged between $14.8^{\circ}$ and $34.1^{\circ}$, with an average of $23.7^{\circ}$. Leaf angle averages in the lower, middle and upper portions were $27.7^{\circ}, 21.4^{\circ}$, and $21.7^{\circ}$, respectively. This showed a greater inclination of the leaves at the base of the plant in relation to the middle and upper portions (Table 3). The leaf angle gradually decreased from the basal leaves towards the upper leaves. Similar results were reported by VIEIRA JUNIOR et al. (2005) in a study to estimate the population and spatial arrangement of maize according to the canopy architecture and 
Table 3 - Means for nine traits of the maize cultivars assessed in three experiments and number of groups formed by the Scott-Knott test.

\begin{tabular}{|c|c|c|c|c|c|c|c|c|c|c|c|c|c|c|c|c|c|c|}
\hline \multirow{2}{*}{$\begin{array}{c}\text { Genotype } \\
20 A 55\end{array}$} & \multicolumn{2}{|l|}{ NL } & \multicolumn{2}{|l|}{ NLBE } & \multicolumn{2}{|l|}{ NLAE } & \multicolumn{2}{|l|}{ PH } & \multicolumn{2}{|l|}{ EIH } & \multicolumn{2}{|l|}{ AGP } & \multicolumn{2}{|l|}{ AGL } & \multicolumn{2}{|l|}{ AGM } & \multicolumn{2}{|l|}{ AGU } \\
\hline & 15.3 & $\mathrm{~b}$ & 7.7 & b & 7.7 & a & 234.5 & a & 110.2 & b & 23.0 & $\mathrm{c}$ & 28.0 & b & 19.5 & $\mathrm{~b}$ & 20.9 & b \\
\hline $30 \mathrm{~A} 68$ & 17.3 & $\mathrm{a}$ & 9.0 & $\mathrm{a}$ & 8.3 & a & 235.0 & $\mathrm{a}$ & 117.2 & b & 22.8 & $\mathrm{c}$ & 27.7 & b & 20.5 & $\mathrm{~b}$ & 19.8 & b \\
\hline $30 \mathrm{~F} 53$ & 15.0 & $\mathrm{~b}$ & 8.0 & $\mathrm{a}$ & 7.0 & a & 232.7 & $\mathrm{a}$ & 127.2 & a & 20.6 & c & 20.8 & c & 17.1 & b & 23.9 & $\mathrm{a}$ \\
\hline AG8780 & 15.7 & b & 9.0 & $\mathrm{a}$ & 6.7 & a & 245.3 & $\mathrm{a}$ & 127.8 & $\mathrm{a}$ & 24.1 & $\mathrm{~b}$ & 32.5 & $\mathrm{a}$ & 19.9 & $\mathrm{~b}$ & 19.0 & $\mathrm{~b}$ \\
\hline AG9025 & 13.7 & d & 8.3 & $\mathrm{a}$ & 5.3 & a & 215.8 & b & 112.0 & b & 20.6 & $\mathrm{c}$ & 24.2 & c & 19.1 & $\mathrm{~b}$ & 17.8 & b \\
\hline AM9724 & 14.7 & $\mathrm{c}$ & 8.0 & $\mathrm{a}$ & 6.7 & $\mathrm{a}$ & 221.9 & b & 119.0 & b & 29.1 & $\mathrm{a}$ & 34.7 & $\mathrm{a}$ & 28.3 & $\mathrm{a}$ & 24.0 & $\mathrm{a}$ \\
\hline AS1666 & 12.7 & d & 7.0 & b & 5.7 & a & 228.0 & b & 113.7 & b & 24.5 & $\mathrm{~b}$ & 23.4 & c & 24.7 & $\mathrm{a}$ & 25.8 & $\mathrm{a}$ \\
\hline AS1677 & 15.0 & b & 8.0 & $\mathrm{a}$ & 7.0 & $\mathrm{a}$ & 219.9 & b & 105.9 & b & 21.1 & $\mathrm{c}$ & 26.8 & c & 19.5 & $\mathrm{~b}$ & 16.3 & $\mathrm{~b}$ \\
\hline BM3066 & 17.3 & $\mathrm{a}$ & 9.3 & a & 8.0 & a & 252.8 & $\mathrm{a}$ & 150.4 & a & 29.9 & $\mathrm{a}$ & 34.1 & a & 26.9 & $\mathrm{a}$ & 28.5 & $\mathrm{a}$ \\
\hline CD324 & 14.3 & $\mathrm{c}$ & 7.7 & $\mathrm{~b}$ & 6.7 & a & 228.3 & b & 116.8 & b & 19.9 & c & 23.8 & c & 17.8 & $\mathrm{~b}$ & 17.3 & $\mathrm{~b}$ \\
\hline CD384 & 13.7 & d & 6.7 & b & 7.0 & a & 228.9 & b & 112.2 & b & 20.7 & $\mathrm{c}$ & 22.5 & c & 19.5 & b & 19.8 & b \\
\hline CD393 & 14.0 & $\mathrm{c}$ & 7.3 & b & 6.7 & a & 242.3 & $\mathrm{a}$ & 123.2 & $\mathrm{a}$ & 23.7 & $\mathrm{~b}$ & 27.7 & b & 23.6 & $\mathrm{a}$ & 19.1 & $\mathrm{~b}$ \\
\hline CD397 & 15.0 & $\mathrm{~b}$ & 8.3 & a & 6.7 & a & 233.0 & $\mathrm{a}$ & 127.9 & $\mathrm{a}$ & 27.6 & $\mathrm{a}$ & 28.7 & b & 23.8 & $\mathrm{a}$ & 30.4 & $\mathrm{a}$ \\
\hline Celeron & 14.0 & $\mathrm{c}$ & 7.0 & b & 7.0 & a & 216.1 & b & 107.8 & b & 27.3 & $\mathrm{a}$ & 33.2 & $\mathrm{a}$ & 28.5 & $\mathrm{a}$ & 19.3 & $\mathrm{~b}$ \\
\hline DKB230 & 13.7 & d & 7.7 & b & 6.0 & a & 215.5 & b & 103.8 & b & 25.9 & $\mathrm{~b}$ & 29.5 & b & 25.1 & $\mathrm{a}$ & 22.2 & $\mathrm{a}$ \\
\hline DKB290 & 15.7 & b & 8.7 & $\mathrm{a}$ & 7.0 & a & 239.2 & $\mathrm{a}$ & 121.9 & b & 15.7 & $\mathrm{c}$ & 22.2 & c & 14.5 & $\mathrm{~b}$ & 10.2 & $\mathrm{~b}$ \\
\hline MS2010 & 14.7 & $\mathrm{c}$ & 7.7 & b & 7.0 & a & 253.2 & a & 129.8 & a & 26.5 & $\mathrm{~b}$ & 29.4 & b & 27.4 & $\mathrm{a}$ & 22.5 & $\mathrm{a}$ \\
\hline MS2013 & 16.0 & $\mathrm{~b}$ & 9.0 & $\mathrm{a}$ & 7.0 & $\mathrm{a}$ & 237.6 & $\mathrm{a}$ & 121.3 & $\mathrm{~b}$ & 25.7 & $\mathrm{~b}$ & 33.0 & $\mathrm{a}$ & 24.7 & $\mathrm{a}$ & 17.9 & $\mathrm{~b}$ \\
\hline MS3022 & 15.7 & $\mathrm{~b}$ & 7.3 & b & 8.3 & a & 211.9 & b & 109.8 & b & 28.7 & $\mathrm{a}$ & 32.9 & a & 28.5 & $\mathrm{a}$ & 23.8 & a \\
\hline P1630 & 12.7 & d & 5.0 & $\mathrm{c}$ & 7.7 & $\mathrm{a}$ & 219.4 & b & 113.3 & b & 27.6 & $\mathrm{a}$ & 28.0 & b & 26.5 & $\mathrm{a}$ & 28.4 & a \\
\hline P2530 & 13.3 & d & 7.7 & b & 5.7 & $\mathrm{a}$ & 227.7 & b & 103.9 & b & 24.3 & $\mathrm{~b}$ & 24.1 & c & 22.9 & $\mathrm{a}$ & 26.2 & a \\
\hline SHS7915 & 15.7 & $\mathrm{~b}$ & 8.3 & $\mathrm{a}$ & 7.3 & a & 215.5 & b & 113.1 & $\mathrm{~b}$ & 23.0 & $\mathrm{c}$ & 25.2 & c & 19.1 & $\mathrm{~b}$ & 24.4 & $\mathrm{a}$ \\
\hline StatusVIP3 & 16.0 & $\mathrm{~b}$ & 9.0 & a & 7.0 & a & 236.8 & a & 133.6 & a & 24.7 & $\mathrm{~b}$ & 28.3 & b & 21.1 & $\mathrm{~b}$ & 23.8 & $\mathrm{a}$ \\
\hline StatusVIP & 15.7 & b & 9.0 & $\mathrm{a}$ & 6.7 & a & 241.7 & $\mathrm{a}$ & 135.9 & a & 24.5 & $\mathrm{~b}$ & 28.4 & b & 20.5 & $\mathrm{~b}$ & 24.0 & $\mathrm{a}$ \\
\hline SX7331 & 15.3 & $\mathrm{~b}$ & 8.0 & $\mathrm{a}$ & 7.3 & $\mathrm{a}$ & 250.0 & $\mathrm{a}$ & 130.9 & $\mathrm{a}$ & 21.5 & $\mathrm{c}$ & 24.3 & c & 20.1 & $\mathrm{~b}$ & 19.8 & $\mathrm{~b}$ \\
\hline XB6012 & 14.7 & $\mathrm{c}$ & 8.0 & $\mathrm{a}$ & 6.7 & a & 229.1 & $\mathrm{~b}$ & 135.0 & a & 20.1 & $\mathrm{c}$ & 27.9 & b & 17.1 & $\mathrm{~b}$ & 15.3 & $\mathrm{~b}$ \\
\hline Number of groups & 4 & & 3 & & 1 & & 2 & & 2 & & 3 & & 3 & & 2 & & 2 & \\
\hline AL2015 & 15.5 & $\mathrm{a}$ & 8.5 & $\mathrm{a}$ & 7.0 & $\mathrm{a}$ & 230.8 & b & 118.3 & a & 22.7 & $\mathrm{a}$ & 26.3 & a & 18.7 & $\mathrm{a}$ & 22.6 & a \\
\hline ALPiratininga & 15.5 & $\mathrm{a}$ & 8.0 & $\mathrm{a}$ & 7.5 & a & 256.5 & $\mathrm{a}$ & 130.0 & $\mathrm{a}$ & 26.3 & $\mathrm{a}$ & 30.9 & $\mathrm{a}$ & 23.2 & $\mathrm{a}$ & 24.7 & $\mathrm{a}$ \\
\hline Embrapa1M1642 & 16.5 & $\mathrm{a}$ & 9.0 & $\mathrm{a}$ & 7.5 & a & 228.3 & b & 117.9 & a & 26.2 & $\mathrm{a}$ & 30.6 & a & 23.4 & $\mathrm{a}$ & 23.7 & a \\
\hline XB61493 & 15.5 & $\mathrm{a}$ & 9.0 & a & 6.5 & a & 243.8 & a & 131.8 & a & 25.0 & $\mathrm{a}$ & 28.3 & a & 24.6 & $\mathrm{a}$ & 21.3 & $\mathrm{a}$ \\
\hline 70XB01 & 16.0 & a & 8.5 & a & 7.5 & a & 256.7 & a & 135.6 & a & 22.7 & a & 21.6 & a & 21.2 & a & 25.6 & $\mathrm{a}$ \\
\hline Balu383VIP3 & 15.0 & $\mathrm{a}$ & 8.0 & $\mathrm{a}$ & 7.0 & a & 256.6 & $\mathrm{a}$ & 131.5 & $\mathrm{a}$ & 25.8 & $\mathrm{a}$ & 31.3 & a & 21.0 & $\mathrm{a}$ & 25.2 & $\mathrm{a}$ \\
\hline Balu388VIP3 & 15.0 & $\mathrm{a}$ & 8.0 & a & 7.0 & a & 251.1 & a & 132.4 & a & 26.5 & $\mathrm{a}$ & 29.5 & a & 22.9 & $\mathrm{a}$ & 26.6 & $\mathrm{a}$ \\
\hline Exp929791 & 15.0 & $\mathrm{a}$ & 8.5 & $\mathrm{a}$ & 6.5 & a & 252.3 & $\mathrm{a}$ & 133.5 & $\mathrm{a}$ & 17.9 & $\mathrm{a}$ & 21.6 & a & 17.3 & $\mathrm{a}$ & 14.8 & $\mathrm{a}$ \\
\hline EXP937891 & 15.0 & a & 8.5 & a & 6.5 & a & 220.8 & b & 114.1 & a & 21.6 & a & 28.6 & a & 18.0 & a & 18.3 & a \\
\hline Exp918391 & 14.5 & $\mathrm{a}$ & 9.0 & $\mathrm{a}$ & 5.5 & a & 259.8 & $\mathrm{a}$ & 140.5 & a & 26.9 & $\mathrm{a}$ & 30.9 & a & 21.3 & $\mathrm{a}$ & 28.6 & $\mathrm{a}$ \\
\hline Balu280PRO & 15.0 & a & 8.5 & a & 6.5 & a & 249.3 & a & 137.6 & a & 16.9 & $\mathrm{a}$ & 20.9 & a & 15.5 & $\mathrm{a}$ & 14.3 & a \\
\hline Balu188 & 14.0 & $\mathrm{a}$ & 8.0 & $\mathrm{a}$ & 6.0 & a & 223.8 & $\mathrm{~b}$ & 124.7 & a & 22.9 & a & 24.7 & a & 22.0 & $\mathrm{a}$ & 21.9 & $\mathrm{a}$ \\
\hline Balu761 & 15.0 & $\mathrm{a}$ & 9.0 & $\mathrm{a}$ & 6.0 & a & 226.8 & b & 133.9 & a & 22.3 & $\mathrm{a}$ & 26.6 & $\mathrm{a}$ & 19.7 & $\mathrm{a}$ & 20.0 & $\mathrm{a}$ \\
\hline Number of groups & 1 & & 1 & & 1 & & 2 & & 1 & & 1 & & 1 & & 1 & & 1 & \\
\hline Cr122 & 15.0 & $\mathrm{a}$ & 8.0 & $\begin{array}{c}\text { perit } \\
\text { a }\end{array}$ & $\begin{array}{r}\text { 10nal } \\
7.0\end{array}$ & $\mathrm{a}$ & $\begin{array}{l}\text { iper-early } \\
211.0\end{array}$ & $\mathrm{a}$ & $\begin{array}{c}\text { h maize } \\
117.6\end{array}$ & $\begin{array}{c}\text { cultt } \\
\text { a }\end{array}$ & 22.2 & $\mathrm{a}$ & 32.6 & $\mathrm{a}$ & 19.0 & $\mathrm{a}$ & 15.1 & $\mathrm{a}$ \\
\hline $98 \mathrm{CV} 02$ & 14.0 & $\mathrm{a}$ & 7.5 & a & 6.5 & a & 261.0 & a & 135.0 & a & 27.6 & $\mathrm{a}$ & 33.9 & a & 21.7 & $\mathrm{a}$ & 27.3 & a \\
\hline $70 \times \mathrm{XB} 03$ & 15.0 & $\mathrm{a}$ & 8.0 & $\mathrm{a}$ & 7.0 & a & 238.1 & $\mathrm{a}$ & 122.6 & $\mathrm{a}$ & 23.8 & $\mathrm{a}$ & 27.6 & a & 21.5 & $\mathrm{a}$ & 22.4 & $\mathrm{a}$ \\
\hline Exp917694 & 14.5 & $\mathrm{a}$ & 8.0 & $\mathrm{a}$ & 6.5 & $\mathrm{a}$ & 237.0 & a & 126.7 & a & 34.1 & $\mathrm{a}$ & 35.7 & a & 31.9 & $\mathrm{a}$ & 35.4 & $\mathrm{a}$ \\
\hline Exp93294 & 16.0 & $\mathrm{a}$ & 8.0 & $\mathrm{a}$ & 8.0 & a & 228.9 & $\mathrm{a}$ & 108.6 & $\mathrm{a}$ & 26.5 & $\mathrm{a}$ & 29.3 & $\mathrm{a}$ & 21.2 & $\mathrm{a}$ & 28.5 & $\mathrm{a}$ \\
\hline EXP942491 & 15.0 & $\mathrm{a}$ & 9.0 & a & 6.0 & a & 222.5 & a & 131.9 & a & 14.8 & $\mathrm{a}$ & 19.9 & a & 13.1 & $\mathrm{a}$ & 10.5 & $\mathrm{a}$ \\
\hline EXP942494 & 15.5 & $\mathrm{a}$ & 9.0 & $\mathrm{a}$ & 6.5 & a & 253.6 & $\mathrm{a}$ & 136.9 & a & 22.3 & $\mathrm{a}$ & 26.3 & a & 20.8 & $\mathrm{a}$ & 19.3 & $\mathrm{a}$ \\
\hline EXP978791 & 15.5 & $\mathrm{a}$ & 8.5 & a & 7.0 & a & 244.7 & a & 119.3 & a & 22.4 & $\mathrm{a}$ & 30.4 & a & 17.4 & $\mathrm{a}$ & 18.4 & $\mathrm{a}$ \\
\hline EXP978894 & 14.5 & a & 7.5 & a & 7.0 & a & 238.3 & a & 123.0 & a & 21.6 & $\mathrm{a}$ & 26.2 & a & 21.7 & $\mathrm{a}$ & 15.9 & a \\
\hline Balu280PRO & 15.0 & $\mathrm{a}$ & 8.5 & $\mathrm{a}$ & 6.5 & a & 232.8 & a & 124.8 & a & 21.3 & $\mathrm{a}$ & 25.8 & a & 17.4 & $\mathrm{a}$ & 20.4 & a \\
\hline Balu188 & 13.5 & $\mathrm{a}$ & 8.0 & a & 5.5 & a & 204.4 & a & 111.3 & $\mathrm{a}$ & 23.8 & $\mathrm{a}$ & 27.0 & a & 21.8 & $\mathrm{a}$ & 22.5 & $\mathrm{a}$ \\
\hline Balu761 & 15.5 & $\mathrm{a}$ & 8.5 & $\mathrm{a}$ & 7.0 & a & 240.3 & $\mathrm{a}$ & 126.9 & a & 22.5 & $\mathrm{a}$ & 27.0 & a & 18.4 & $\mathrm{a}$ & 21.2 & $\mathrm{a}$ \\
\hline Number of groups & 1 & & 1 & & 1 & & 1 & & 1 & & 1 & & 1 & & 1 & & 1 & \\
\hline
\end{tabular}

Traits: NL: number of leaves; NLBE: number of leaves below the ear; NLAE: number of leaves above the ear; PH: plant height, in cm; EIH: ear insertion height, in cm; AGP: leaf angle of the plant, in degrees; AGL: leaf angle of the lower portion, in degrees; AGM: leaf angle of the middle portion, in degrees; AGU: leaf angle of the upper portion, in degrees. Means in the column not followed by the same letter are significantly different by the Scott-Knott test, at $5 \%$ significance. 
Table 4 - Means for 13 traits of the maize cultivars assessed in three experiments; number of groups formed by the Scott-Knott test.

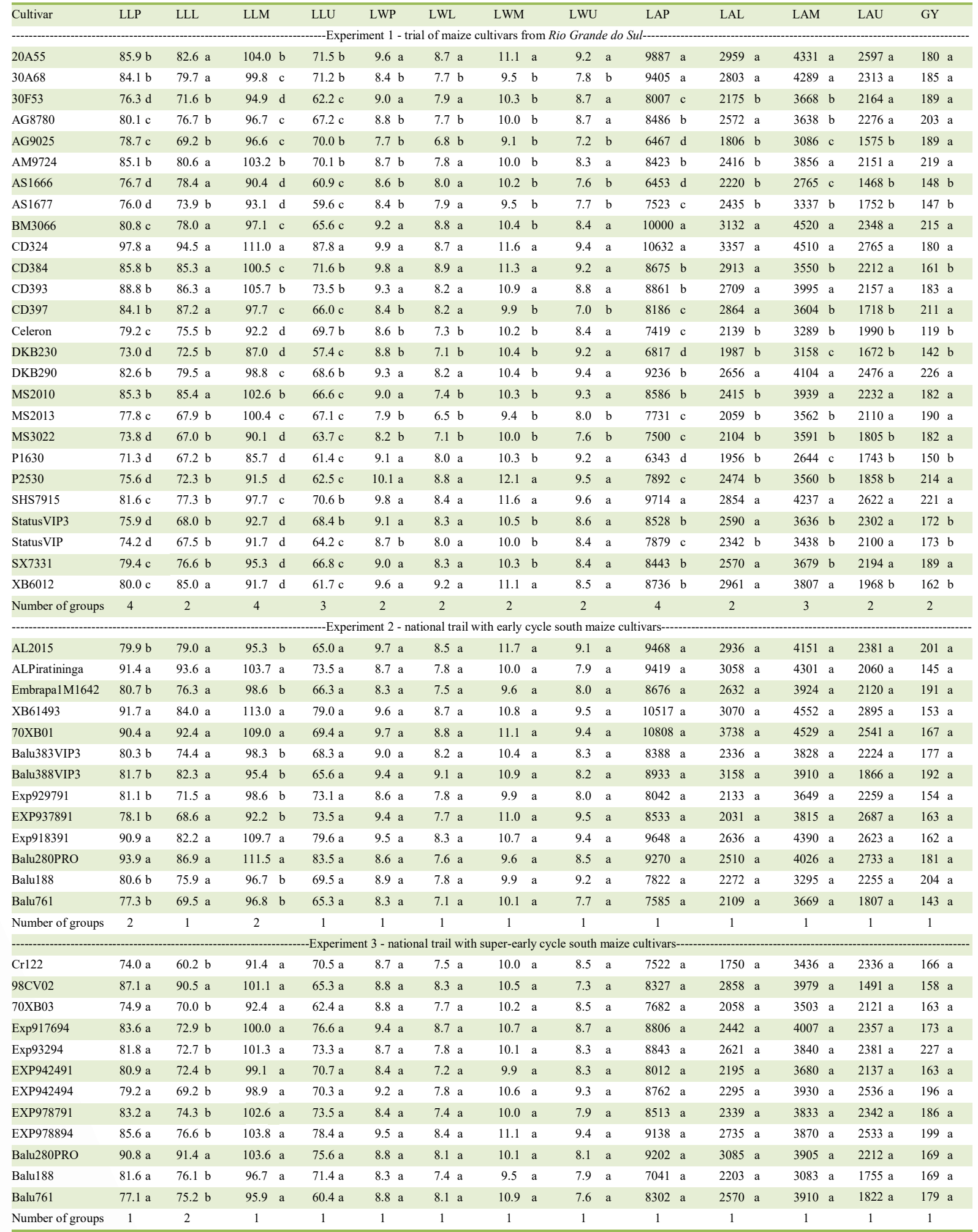

Traits: LLP: leaf length of the plant, in cm; LLL: leaf length of the lower portion, in cm; LLM: leaf length of the middle portion, in cm; LLU: leaf length of the upper portion, in cm; LWP: leaf width of the plant, in cm; LWL: leaf width of the lower portion, in cm; LWM: leaf width of the middle portion, in cm; LWU: leaf width of the upper portion, in cm; LAP: leaf area of the plant, in $\mathrm{cm}^{2}$; LAL: leaf area of the lower portion, in $\mathrm{cm}^{2}$; LAM: leaf area of the middle portion, in $\mathrm{cm}^{2}$; LAU: leaf area of the upper portion, in $\mathrm{cm}^{2}$; and GY: grain yield, in $\mathrm{g} \mathrm{plant}{ }^{-1}$. Means in the column not followed by the same letter are significantly different by the Scott-Knott test, at $5 \%$ significance. 
crop location. They found that the average leaf angle varied between $16^{\circ}$ and $37^{\circ}$. These values are also in agreement with the results obtained by KU et al. (2010), WASSOM (2013), and ZHANG et al. (2014), of $27.5^{\circ}, 26.0^{\circ}$, and $23.9^{\circ}$, respectively, for the average leaf angle. However, VIEIRA JUNIOR et al. (2006) recorded greater angles for three open pollinated varieties, eight double hybrids, eight triple hybrids, ten simple hybrids, and 15 lines, with average value of $38.67^{\circ}$, varying between $19^{\circ}$ and $43^{\circ}$.

Grain yield is increased in plants with more upright leaves, with smaller leaf angles, which allow plant density to be increased, and favor light capture for photosynthesis (TIAN et al., 2011; ZHANG et al., 2014; HUANG et al., 2017). An ideotype of a compact plant, having shorter plants with fewer and more erect leaves, improves the quality of light within the canopy and reduces the dominance of the tassel (apical) over the ears (SANGOI et al., 2002). In this sense, the selection of plants with smaller leaf insertion angle, larger stem diameter, and higher thousand-grain mass may increase grain yield (NARDINO et al., 2016).

Plant leaf length (LLP) varied between 71.3 and $97.8 \mathrm{~cm}$, with average of $81.7 \mathrm{~cm}$ (Table 4). Similar leaf lengths were recorded in other studies; for instance, between 64 and $108 \mathrm{~cm}$ (VIEIRAJUNIOR et al., 2005), between 52 and $106 \mathrm{~cm}$ (VIEIRA JUNIOR et al., 2006), average of $85.90 \mathrm{~cm}$ (KU et al., 2010), and average of $76.46 \mathrm{~cm}$ (WASSOM, 2013). In the lower, middle and upper portions, the average leaf length was of $77.3,98.3$, and $69.1 \mathrm{~cm}$, respectively. This showed that the leaves were shorter at the base and top of the plant, and longer in the central part of the plant. The increases in the base and top towards the middle part of the plant were gradual.

A similar pattern was observed in relation to leaf width (LWP), which varied between 7.7 and $10.1 \mathrm{~cm}$, with average of $8.9 \mathrm{~cm}$ (Table 4). Higher values were found by VIEIRA JUNIOR et al. (2005): between 21 and $27 \mathrm{~cm}$. Similar values were found by VIEIRA JUNIOR et al., 2006: between 4.5 and 14.5 $\mathrm{cm}$. The average leaf width in this study $(8.9 \mathrm{~cm})$ was similar to the results reported by KU et al. (2010) $(8.89 \mathrm{~cm})$ and WASSOM (2013) $(9.1 \mathrm{~cm})$. Leaf width gradually increased from the lower portion (average= $8.0 \mathrm{~cm}$ ) and the upper portion (average $=8.5 \mathrm{~cm}$ ) towards the middle portion (average $=10.4 \mathrm{~cm}$ ) of the plant.

Plant leaf area (LAP) varied between 6,343 and $10,808 \mathrm{~cm}^{2}$, with average of $8,492 \mathrm{~cm}^{2}$. The patterns for leaf length and leaf width can explain the gradual increase of the leaf area in the lower portion (average $=2,534 \mathrm{~cm}^{2}$ ) and the upper portion (average=
$2,177 \mathrm{~cm}^{2}$ ) towards the middle portion (average $=3,781$ $\mathrm{cm}^{2}$ ). Similar leaf area, between 1,177.67 and 9,244.24 $\mathrm{cm}^{2}$, was estimated by VIEIRA JUNIOR et al. (2006). Conversely, HANASHIRO et al. (2013) assessed maize cultivars and found two groups in relation to the leaf area of the leaf above and opposite to the first ear: the first group varied between 796 and $883 \mathrm{~cm}^{2}$ and the second group between 668 and $783 \mathrm{~cm}^{2}$, which was lower than the results of this study. Cultivars with high leaf areas and leaves with greater insertion angle demand more space between the rows and lower plant density per area, in order to minimize competition for water, light, and nutrients, which results in lower yield.

Results showed that the leaves close to the ear (middle portion) had smaller leaf angle and greater leaf length, leaf width, and leaf area. There was a gradual increase of leaf angle towards the leaves at the lower end of the plant, while a gradual decrease of leaf length, leaf width, and leaf area occurred towards the leaves at the lower and upper end of the plant. Therefore, in relation to the basal leaves, the leaves close to the ear were more erect, longer, wider, and had greater leaf area.

Grain yield (GY) ranged between 119 and $227 \mathrm{~g} \mathrm{plant}^{-1}$, with an average of $179 \mathrm{~g} \mathrm{plant}^{-1}$ (Table 4). Similar results were described by HANASHIRO et al. (2013), who found grain yield ranging from 5,926 to $14,419 \mathrm{~kg} \mathrm{ha}^{-1}$ in a population of 60,000 plants ha-1, resulting in 98.77 and 240.32 g plant $^{-1}$, respectively. In the 2008/2009 harvest year, TOEBE et al. (2014) reported the following values for grain yield per plant: $131.44,153.25$ and 144.85 g plant $^{-1}$, for single, triple, and double hybrids, respectively. In the 2009/2010 harvest year, the numbers were recorded as follows: $115.68,116.62$, and $86.37 \mathrm{~g} \mathrm{plant}^{-1}$ for single, triple, and double hybrids, respectively, which were values below those found in the present study.

The Pearson's correlation coefficient (r) showed a positive linear association between the traits NL and NLBE $(r=0.72)$ and NL and NLAE $(\mathrm{r}=0.63)$. Plants with greater height are associated with higher ear insertion height $(r=0.75)$. The traits related to leaf angle (AGP, AGL, AGM, and AGU) had a positive linear correlation $(0.45 \leq \mathrm{r} \leq 0.90)$. A positive linear relationship was reported between the traits related to leaf length (LLP, LLL, LLM, and LLU; $0.38 \leq \mathrm{r} \leq 0.93$ ), leaf width (LWP, LWL, LWM, and LWU; $0.40 \leq \mathrm{r} \leq 0.93$ ), and leaf area (LAP, LAL, LAM, and LAU; $0.36 \leq \mathrm{r} \leq 0.95$ ) (Table 5).

Grain yield showed no linear correlation with the groups of traits related to plant height $(\mathrm{PH}$ and EIH; $0.03 \leq \mathrm{r} \leq 0.07$ ), leaf angle (AGP, AGL, AGM, and AGU; $-0.07 \leq \mathrm{r} \leq 0.10$ ), leaf length (LLP, LLL, LLM, and LLU; $0.00 \leq \mathrm{r} \leq 0.15$ ), and leaf width 
Table 5 - Pearson's correlation coefficient matrix (phenotypic correlation) based on the means for 22 traits of 51 maize cultivars.

\begin{tabular}{|c|c|c|c|c|c|c|c|c|c|c|c|}
\hline & NL & NLBE & NLAE & PH & $\mathrm{EIH}$ & AGP & AGL & AGM & AGU & LLP & LLL \\
\hline NL & - & & & & & & & & & & \\
\hline NLBE & $0.72^{*}$ & - & & & & & & & & & \\
\hline NLAE & $0.63^{*}$ & $-0.09 \mathrm{~ns}$ & - & & & & & & & & \\
\hline $\mathrm{PH}$ & $0.33^{*}$ & $0.30^{*}$ & $0.13 \mathrm{~ns}$ & - & & & & & & & \\
\hline EIH & $0.37^{*}$ & $0.50^{*}$ & $-0.02 \mathrm{~ns}$ & $0.75^{*}$ & - & & & & & & \\
\hline AGP & $0.00 \mathrm{~ns}$ & $-0.19 \mathrm{~ns}$ & $0.21 \mathrm{~ns}$ & $0.07 \mathrm{~ns}$ & $-0.01 \mathrm{~ns}$ & - & & & & & \\
\hline AGL & $0.18 \mathrm{~ns}$ & $0.01 \mathrm{~ns}$ & $0.25 \mathrm{~ns}$ & $0.05 \mathrm{~ns}$ & $0.02 \mathrm{~ns}$ & $0.81^{*}$ & - & & & & \\
\hline AGM & $-0.15 \mathrm{~ns}$ & $-0.33^{*}$ & $0.16 \mathrm{~ns}$ & $-0.05 \mathrm{~ns}$ & $-0.12 \mathrm{~ns}$ & $0.90^{*}$ & $0.66^{*}$ & - & & & \\
\hline AGU & $-0.06 \mathrm{~ns}$ & $-0.18 \mathrm{~ns}$ & $0.12 \mathrm{~ns}$ & $0.16 \mathrm{~ns}$ & $0.07 \mathrm{~ns}$ & $0.84^{*}$ & $0.45^{*}$ & $0.65^{*}$ & - & & \\
\hline LLP & $0.09 \mathrm{~ns}$ & $0.13 \mathrm{~ns}$ & $-0.03 \mathrm{~ns}$ & $0.44^{*}$ & $0.30^{*}$ & $-0.11 \mathrm{~ns}$ & $-0.11 \mathrm{~ns}$ & $-0.12 \mathrm{~ns}$ & $-0.04 \mathrm{~ns}$ & - & \\
\hline \multirow[t]{2}{*}{ LLL } & $-0.02 \mathrm{~ns}$ & $-0.05 \mathrm{~ns}$ & $0.03 \mathrm{~ns}$ & $0.42^{*}$ & $0.24 \mathrm{~ns}$ & $-0.04 \mathrm{~ns}$ & $-0.13 \mathrm{~ns}$ & $-0.05 \mathrm{~ns}$ & $0.08 \mathrm{~ns}$ & $0.85^{*}$ & - \\
\hline & NL & NLBE & NLAE & $\mathrm{PH}$ & EIH & AGP & AGL & AGM & $\mathrm{AGU}$ & LLP & LLL \\
\hline LLM & $0.22 \mathrm{~ns}$ & $0.29^{*}$ & $-0.01 \mathrm{~ns}$ & $0.49^{*}$ & $0.35^{*}$ & $-0.13 \mathrm{~ns}$ & $-0.11 \mathrm{~ns}$ & $-0.14 \mathrm{~ns}$ & $-0.08 \mathrm{~ns}$ & $0.93^{*}$ & $0.66^{*}$ \\
\hline LLU & $0.07 \mathrm{~ns}$ & $0.17 \mathrm{~ns}$ & $-0.09 \mathrm{~ns}$ & $0.19 \mathrm{~ns}$ & $0.16 \mathrm{~ns}$ & $-0.18 \mathrm{~ns}$ & $-0.09 \mathrm{~ns}$ & $-0.17 \mathrm{~ns}$ & $-0.18 \mathrm{~ns}$ & $0.79^{*}$ & $0.38^{*}$ \\
\hline LWP & $-0.09 \mathrm{~ns}$ & $-0.17 \mathrm{~ns}$ & $0.06 \mathrm{~ns}$ & $0.21 \mathrm{~ns}$ & $0.09 \mathrm{~ns}$ & $-0.02 \mathrm{~ns}$ & $-0.18 \mathrm{~ns}$ & $-0.05 \mathrm{~ns}$ & $0.15 \mathrm{~ns}$ & $0.29^{*}$ & $0.34^{*}$ \\
\hline LWL & $-0.01 \mathrm{~ns}$ & $-0.13 \mathrm{~ns}$ & $0.13 \mathrm{~ns}$ & $0.34^{*}$ & $0.25 \mathrm{~ns}$ & $0.07 \mathrm{~ns}$ & $-0.12 \mathrm{~ns}$ & $-0.03 \mathrm{~ns}$ & $0.30^{*}$ & $0.35^{*}$ & $0.49^{*}$ \\
\hline LWM & $-0.14 \mathrm{~ns}$ & $-0.20 \mathrm{~ns}$ & $0.02 \mathrm{~ns}$ & $0.12 \mathrm{~ns}$ & $-0.04 \mathrm{~ns}$ & $-0.02 \mathrm{~ns}$ & $-0.16 \mathrm{~ns}$ & $-0.06 \mathrm{~ns}$ & $0.15 \mathrm{~ns}$ & $0.20 \mathrm{~ns}$ & $0.28^{*}$ \\
\hline LWU & $-0.08 \mathrm{~ns}$ & $-0.11 \mathrm{~ns}$ & $0.00 \mathrm{~ns}$ & $0.06 \mathrm{~ns}$ & $-0.03 \mathrm{~ns}$ & $-0.13 \mathrm{~ns}$ & $-0.22 \mathrm{~ns}$ & $-0.04 \mathrm{~ns}$ & $-0.07 \mathrm{~ns}$ & $0.18 \mathrm{~ns}$ & $0.08 \mathrm{~ns}$ \\
\hline LAP & $0.54^{*}$ & $0.39^{*}$ & $0.35^{*}$ & $0.51^{*}$ & $0.40^{*}$ & $-0.07 \mathrm{~ns}$ & $-0.05 \mathrm{~ns}$ & $-0.17 \mathrm{~ns}$ & $0.02 \mathrm{~ns}$ & $0.75^{*}$ & $0.63^{*}$ \\
\hline LAL & $0.34^{*}$ & $0.16 \mathrm{~ns}$ & $0.31^{*}$ & $0.45^{*}$ & $0.32^{*}$ & $0.02 \mathrm{~ns}$ & $-0.09 \mathrm{~ns}$ & $-0.08 \mathrm{~ns}$ & $0.19 \mathrm{~ns}$ & $0.69^{*}$ & $0.81^{*}$ \\
\hline LAM & $0.61^{*}$ & $0.48^{*}$ & $0.34^{*}$ & $0.55^{*}$ & $0.44^{*}$ & $-0.01 \mathrm{~ns}$ & $0.07 \mathrm{~ns}$ & $-0.13 \mathrm{~ns}$ & $0.04 \mathrm{~ns}$ & $0.70^{*}$ & $0.56^{*}$ \\
\hline LAU & $0.44^{*}$ & $0.37^{*}$ & $0.23 \mathrm{~ns}$ & $0.29^{*}$ & $0.25 \mathrm{~ns}$ & $-0.23 \mathrm{~ns}$ & $-0.13 \mathrm{~ns}$ & $-0.25 \mathrm{~ns}$ & $-0.21 \mathrm{~ns}$ & $0.51^{*}$ & $0.18 \mathrm{~ns}$ \\
\hline \multirow[t]{2}{*}{ GY } & $0.36^{*}$ & $0.28^{*}$ & $0.21 \mathrm{~ns}$ & $0.07 \mathrm{~ns}$ & $0.03 \mathrm{~ns}$ & $0.01 \mathrm{~ns}$ & $-0.02 \mathrm{~ns}$ & $-0.07 \mathrm{~ns}$ & $0.10 \mathrm{~ns}$ & $0.06 \mathrm{~ns}$ & $0.00 \mathrm{~ns}$ \\
\hline & LLM & LLU & LWP & LWL & LWM & LWU & LAP & LAL & LAM & LAU & GY \\
\hline LLM & - & & & & & & & & & & \\
\hline LLU & $0.79^{*}$ & - & & & & & & & & & \\
\hline LWP & $0.20 \mathrm{~ns}$ & $0.20 \mathrm{~ns}$ & - & & & & & & & & \\
\hline LWL & $0.21 \mathrm{~ns}$ & $0.12 \mathrm{~ns}$ & $0.84^{*}$ & - & & & & & & & \\
\hline LWM & $0.11 \mathrm{~ns}$ & $0.11 \mathrm{~ns}$ & $0.93^{*}$ & $0.74^{*}$ & - & & & & & & \\
\hline LWU & $0.19 \mathrm{~ns}$ & $0.29^{*}$ & $0.80^{*}$ & $0.40^{*}$ & $0.66^{*}$ & - & & & & & \\
\hline LAP & $0.74^{*}$ & $0.58^{*}$ & $0.60^{*}$ & $0.59^{*}$ & $0.49^{*}$ & $0.44^{*}$ & - & & & & \\
\hline LAL & $0.57^{*}$ & $0.30^{*}$ & $0.56^{*}$ & $0.73^{*}$ & $0.49^{*}$ & $0.21 \mathrm{~ns}$ & $0.84^{*}$ & - & & & \\
\hline LAM & $0.72^{*}$ & $0.51^{*}$ & $0.47^{*}$ & $0.46^{*}$ & $0.41^{*}$ & $0.31^{*}$ & $0.95^{*}$ & $0.74^{*}$ & - & & \\
\hline LAU & $0.61^{*}$ & $0.71^{*}$ & $0.51^{*}$ & $0.29^{*}$ & $0.34^{*}$ & $0.67^{*}$ & $0.77^{*}$ & $0.36^{*}$ & $0.69^{*}$ & - & \\
\hline GY & $0.15 \mathrm{~ns}$ & $0.07 \mathrm{~ns}$ & $0.16 \mathrm{~ns}$ & $0.16 \mathrm{~ns}$ & $0.13 \mathrm{~ns}$ & $0.15 \mathrm{~ns}$ & $0.30^{*}$ & $0.21 \mathrm{~ns}$ & $0.29^{*}$ & $0.27 \mathrm{~ns}$ & - \\
\hline
\end{tabular}

Traits: NL: number of leaves; NLBE: number of leaves below the ear; NLAE: number of leaves above the ear; PH: plant height, in cm; EIH: ear insertion height, in cm; AGP: leaf angle of the plant, in degrees; AGL: leaf angle of the lower portion, in degrees; AGM: leaf angle of the middle portion, in degrees; AGU: leaf angle of the upper portion, in degrees; LLP: leaf length of the plant, in cm; LLL: leaf length of the lower portion, in cm; LLM: leaf length of the middle portion, in cm; LLU: leaf length of the upper portion, in cm; LWP: leaf width of the plant, in cm; LWL: leaf width of the lower portion, in cm; LWM: leaf width of the middle portion, in cm; LWU: leaf width of the upper portion, in cm; LAP: leaf area of the plant, in $\mathrm{cm}^{2}$; LAL: leaf area of the lower portion, in $\mathrm{cm}^{2}$; LAM: leaf area of the middle portion, in $\mathrm{cm}^{2}$; LAU: leaf area of the upper portion, in $\mathrm{cm}^{2}$; and GY: grain yield, in g plant ${ }^{-1} *$ Significant by the Student's t test at $5 \%$ significance, with 49 degrees of freedom; ${ }^{\text {ns }}$ non-significant.

(LWP, LWL, LWM, and LWU; $0.13 \leq \mathrm{r} \leq 0.16$ ) (Table 5). Differently from this study, BELLO et al. (2010) assessed maize hybrids grown in Nigeria and found a positive correlation between plant height $(r=0.56)$ and ear insertion height $(\mathrm{r}=0.45)$ with grain yield. Conversely, NARDINO et al. (2016) also reported that there was no linear correlation between leaf angle and grain yield $(\mathrm{r}=-0.004)$, which agrees with 
our results. Therefore, the selection of plants using plant height, ear height, number of seeds per row, and hundred seed weight improves maize grain yield (BEKELE \& RAO, 2014).

The groups of traits related to the number of leaves (NL, NLBE, and NLAE; $0.21 \leq r \leq 0.36$ ) and leaf area (LAP, LAL, LAM, and LAU; $0.21 \leq \mathrm{r} \leq$ 0.30 ) had a positive linear association with GY, but of small magnitude (Table 5). A positive correlation between NLAE and GY $(\mathrm{r}=0.21)$ is important because the physiologically active leaf area above the ear is characterized as the most efficient in grain yield (ALVIM et al., 2010). Therefore, cultivars with higher number of leaves $(r=0.36)$ or higher leaf area $(r=0.30)$ are linearly associated with plants with higher grain yield. These results indicated that plants with more leaves and higher leaf area are more productive. NARDINO et al. (2016) also described a positive phenotypic correlation between leaf area and grain yield $(\mathrm{r}=0.284)$. The results of this research are consistent with those of OGUNNIYAN \& OLAKOJO (2014), who reported positive phenotypic correlation between number of leaves per plant $(r=0.83)$ and leaf area $(r=0.37)$ with grain yield.

Considering the 51 cultivars $(3$ varieties, 2 double hybrids, 7 triple hybrids, and 39 simple hybrids), the average of NL, PH $(\mathrm{cm}), \mathrm{EIH}(\mathrm{cm})$, AGP (degrees), LLP $(\mathrm{cm}), \operatorname{LWP}(\mathrm{cm}), \operatorname{LAP}\left(\mathrm{cm}^{2}\right)$, and GY (g plant $\left.{ }^{-1}\right)$ was 15.0, 249.4, 127.8, 25.5, $86.1,9.1,9,072$, and 168 for the varieties; 15.3, $233.6,130.4,22.4,77.2,8.6,7,944$, and 161 for the double hybrids; $14.6,221.1,116.2,24.1,80.8,8.8$, 8,091 , and 182 for triple hybrids; and 15.0, 236.4, $123.9,23.6,81.8,9.0,8,547$, and 180 for the simple hybrids, respectively. Comparisons between genetic bases must be considered with caution due to the low representation the varieties, double hybrids, and triple hybrids had in this data set.

The averages for the traits NL, PH $(\mathrm{cm})$, EIH $(\mathrm{cm})$, AGP (degrees), LLP $(\mathrm{cm}), \operatorname{LWP}(\mathrm{cm}), \operatorname{LAP}$ $\left(\mathrm{cm}^{2}\right)$, and GY $\left(\mathrm{g}\right.$ plant $\left.{ }^{-1}\right)$ were: 15.2, 239.8, 127.4, $23.5,83.0,9.0,8,844$, and 180 for the 29 early-cycle cultivars and 14.6, 228.5, 117.9, 24.1, 80.1, 8.8, 8,028 , and 176 for the 22 super-early cycle cultivars, respectively. These results indicated that early-cycle cultivars are taller plants, with more leaves and with higher ear insertion height. The leaves are more erect, longer and wider, with larger leaf area, and are more productive than super-early cycle cultivars.

Regarding the regions of adaptation (state and national levels), the averages for the traits NL, PH $(\mathrm{cm})$, EIH $(\mathrm{cm})$, AGP (degrees), LLP $(\mathrm{cm})$, LWP $(\mathrm{cm})$, LAP $\left(\mathrm{cm}^{2}\right)$, and GY $\left(\mathrm{g} \mathrm{plant}^{-1}\right)$ were: 14.9 , $231.2,120.1,24.0,80.4,9.0,8,301$, and 182 for the 26 cultivars of the state trial (experiment 1 ) and 15.1, $238.7,126.6,23.5,83.1,8.9,8,690$, and 175 for the
25 cultivars of national trials (experiments 2 and 3 ), respectively. Results indicated that the cultivars from experiment 1 are shorter plants, with fewer leaves, shorter ear insertion height. Their leaves are less erect, shorter and wider, with smaller leaf area and are more productive than the cultivars from experiments 2 and 3 .

The data on the average pattern of plant architecture and the grain yield among the genetic bases, cycles, and regions of adaptation were presented as complementary information, considering it was not the focus of this study. Further studies, using statistical criteria, need to be carried out to detail the comparisons among genetic bases, among cycles, and among regions of adaptation. They also need to include a larger number of cultivars, locations and years (environments), in order to achieve a higher level of representation in the data set.

\section{CONCLUSION}

Genetic variability was reported among cultivars for number of leaves, plant height, ear height, leaf angle, leaf length, leaf width, leaf area, and grain yield.

Leaves closer to the ear have smaller leaf angle, greater leaf length, greater leaf width, and greater leaf area. The leaf angle gradually increases towards the leaves at the lower and upper ends of the plant. Leaf length, leaf width, and leaf area gradually decreases towards the leaves of the lower and upper ends of the plant.

Cultivars with a greater number of leaves and a larger leaf area are associated with plants with higher grain yield.

\section{ACKNOWLEDGEMENTS}

The authors thank to the Conselho Nacional de Desenvolvimento Científico e Tecnológico $(\mathrm{CNPq}$ - process number 401045/2016-1 and 304652/2017-2), Coordenação de Aperfeiçoamento de Pessoal de Nível Superior (CAPES) and Fundação de Amparo à Pesquisa do Estado do Rio Grande do Sul (FAPERGS) by scholarships and financial support.

\section{DECLARATION OF CONFLICT OF} INTERESTS

The authors declare no conflict of interest. The founding sponsors had no role in the design of the study; in the collection, analyses, or interpretation of data; in the writing of the manuscript, and in the decision to publish the results.

\section{AUTHORS' CONTRIBUTIONS}

All authors contributed equally for the conception and writing of the manuscript. All authors critically revised the manuscript and approved of the final version. 


\section{REFERENCES}

ALVARES, C.A. et al. Köppen's climate classification map for Brazil. Meteorologische Zeitschrift, v.22, p.711-728, 2013. Available from: <http://dx.doi.org/10.1127/0941-2948/2013/0507>. Accessed: Jul. 05, 2020. doi: 10.1127/0941-2948/2013/0507.

ALVIM, K.R.T. et al. Quantification of leaf area and defoliation effect in corn crop components. Ciência Rural, v.40, p.1017-1022, 2010. Available from: $<\mathrm{http} / /$ www.scielo.br/scielo.php?script $=$ sci arttext\&pid $=\mathrm{S} 0103-84782010000500003 \& \operatorname{lng}=\mathrm{en} \& \mathrm{nrm}=\mathrm{iso}>$. Accessed: Jul. 05, 2020. doi: 10.1590/S0103-84782010000500003.

ARGENTA, G. et al. Maize plant arrangement: analysis of the state of the art. Ciência Rural, v.31, p.1075-1084, 2001. Available from: $<$ http://www.scielo.br/scielo.php?script=sci_arttext\&pid=S010384782001000600027\&lng=en\&nrm=iso $>$. A Accessed: Jul. 05 , 2020. doi: 10.1590/S0103-84782001000600027.

BEKELE, A.; RAO, T.N. Estimates of herdability, genetic advance and correlation study for yield and it's atributes in maize (Zea mays L.). Journal of Plant Sciences, v.2, p.1-4, 2014. Available from: $<$ http://www.sciencepublishinggroup.com/journal/paperinfo?jour nalid $=215 \&$ doi $=10.11648 /$ j.jps.20140201.11>. Accessed: Jul. 05, 2020. doi: $10.11648 /$ j.jps.20140201.11.

BELLO, O.B. et al. Correlation and path coefficient analysis of yield and agronomic characters among open pollinated maize varieties and their $F_{1}$ hybrids in a diallel cross. African Journal of Biotechnology, v.9, p.2633-2639, 2010.

BORELLA, J. et al. Foliar architecture in corn populations of contrasting cycles. Brazilian Journal of Biosystems Engineering, v.13, p.168-177, 2019. Available from: <http:// dx.doi.org/10.18011/bioeng2019v13n2p168-177>. Accessed: Jul. 05, 2020. doi: 10.18011/bioeng2019v13n2p168-177.

CARGNELUTTI FILHO, A. et al. Number of replicates and experimental precision statistics in corn. Pesquisa Agropecuária Brasileira, v.53, p.1213-1221, 2018. Available from: <http:/ www.scielo.br/scielo.php?script $=$ sci_arttext\&pid $=$ S0100-204X20 18001101213\&lng=en\&nrm=iso $>$. Accessed: Jul. 05, 2020. doi: 10.1590/S0100-204X2018001100003.

CRUZ, C.D. Genes Software - extended and integrated with the $\mathrm{R}$, Matlab and Selegen. Acta Scientiarum Agronomy, v.38, p.547-552, 2016. Available from: <http://www.scielo.br/scielo. php?script $=$ sci arttext\&pid $=$ S1807-86212016000400547\&lng=e n\&nrm=iso $>$. Accessed: Jul. 05, 2020. doi: 10.4025/actasciagron. v38i4.32629.

ELINGS, A. Estimation of leaf area in tropical maize. Agronomy Journal, v.92, p.436-444, 2000. Available from: $<$ http://dx.doi org/10.2134/agronj2000.923436x>. Accessed: Jul. 05, 2020. doi: 10.2134/agronj2000.923436x.

HANASHIRO, R.K. et al.Agronomic, morphologic, and phenologic performance of maize cultivars in Jaboticabal, state of São Paulo, Brazil. Científica, v.41, p.226-234, 2013. Available from: <http:// cientifica.org.br/index.php/cientifica/article/view/410>. Accessed: Jul. 05, 2020. doi: 10.15361/1984-5529.2013v41n2p226-234.

HUANG, S. et al. Influence of plant architecture on maize physiology and yield in the Heilonggang River valley. The Crop Journal, v.5, p.52-62, 2017. Available from: <http://dx.doi. org/10.1016/j.cj.2016.06.018>. Accessed: Jul. 05, 2020. doi: 10.1016/j.cj.2016.06.018.
KU,L.X.etal.Quantitative trait locimapping of leafangleandleaforientation value in maize (Zea mays L.). Theoretical and Applied Genetics, v.121, p.951-959, 2010. Available from: <http://dx.doi.org/10.1007/s00122-0101364-z>. Accessed: Jul. 05, 2020. doi: 10.1007/s00122-010-1364-z.

NARDINO, M. et al. Association of secondary traits with yield in maize F's. Ciência Rural, v.46, p.776-782, 2016. Available from: $<$ http://www.scielo.br/scielo.php?script=sci_arttext\&pid=S010384782016000500776\&lng=en\&nrm=iso $>$. Accessed: Jul. 05, 2020. doi: 10.1590/0103-8478cr20150253.

OGUNNIYAN, D.J.; OLAKOJO, S.A. Genetic variation, heritability, genetic advance and agronomic character association of yellow elite inbred lines of maize (Zea mays L.). Nigerian Journal of Genetics, v.28, p.24-28, 2014. '

PIMENTEL-GOMES, F. Curso de estatística experimental. 15. ed. Piracicaba: FEALQ, 2009. 451p.

RESENDE, M.D.V.; DUARTE, J.B. Precisão e controle de qualidade em experimentos de avaliação de cultivares. Pesquisa Agropecuária Tropical, v.37, p.182-194, 2007.

SANGOI, L. et al. Morpho-physiological bases for greater tolerance of modern maize hybrids to high plant densities. Bragantia, v.61, p.101-110, 2002. Available from: <http://www.scielo.br/scielo. php? script $=$ sci_arttext\&pid $=$ S0006-87052002000200003\&lng $=$ en $\&$ nrm $=$ iso $>$. Accessed: Jul. 05, 2020. doi: 10.1590/S000687052002000200003 .

SANTOS, H.G. et al. Sistema brasileiro de classificação de solos. 5.ed. Brasília, DF: Embrapa Solos, 2018. 356p.

STORCK, L. et al. Experimentação vegetal. 3. ed. Santa Maria: UFSM, 2016. 198p.

TIAN, F. et al. Genome-wide association study of leaf architecture in the maize nested association mapping population. Nature Genetics, v.43, p.159-162, 2011. Available from: <http://dx.doi.org/10.1038/ ng.746>. Accessed: Jul. 05, 2020. doi: 10.1038/ng.746.

TOEBE, M. et al. Sample size for the estimation of the mean and the coefficient of variation in maize. Pesquisa Agropecuária Brasileira, v.49, p.860-871, 2014. Available from: < http://www. scielo.br/scielo.php?script $=$ sci arttext\&pid $=\mathrm{S} 0100-204 \mathrm{X} 2014$ 001100860\&lng=en\&nrm=iso $>$. Accessed: Jul. 05, 2020. doi: 10.1590/S0100-204X2014001100005.

VIEIRA JUNIOR, P.A. et al. Methodology to estimate maize genotypes leaf area. Revista Brasileira de Milho e Sorgo, v.5, p.182-191, 2006. Available from: <http://rbms.cnpms.embrapa. br/index.php/ojs/article/view/181>. Accessed: Jul. 05, 2020. doi: 10.18512/1980-6477/rbms.v5n2p182-191.

VIEIRA JUNIOR, P.A. et al. Forecast of the population and spatial arrangement of maize due to canopy architecture and crop localization. Revista Brasileira de Milho e Sorgo, v.4, p.404-417, 2005. Available from: <http://rbms.cnpms.embrapa.br/index.php/ojs/article/view/160>. Accessed: Jul. 05, 2020. doi: 10.18512/1980-6477/rbms.v4n3p404-417.

WASSOM, J.J. Quantitative trait loci for leaf angle, leaf width, leaf length, and plant height in a maize (Zea mays L) B73 $\times$ Mo17 population. Maydica, v.58, p.318-321, 2013.

ZHANG, J. et al. The ZmCLA4 gene in the qLA4-1QTL controls leaf angle in maize (Zea mays L.). Journal of Experimental Botany, v.65, p.5063-5076, 2014. Available from: <http://dx.doi. org/10.1093/jxb/eru271>. Accessed: Jul. 05, 2020. 